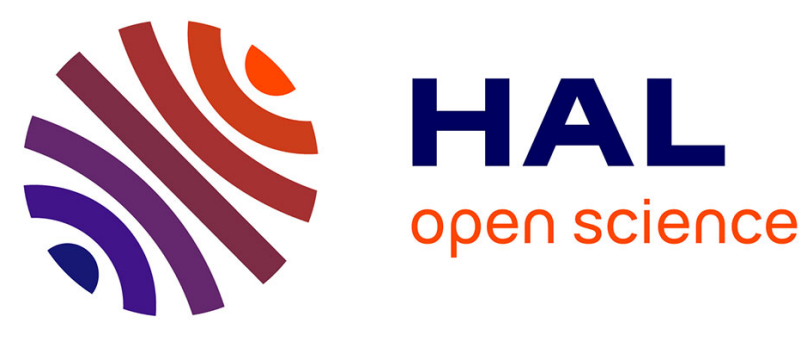

\title{
Giant-cell arteritis-related mortality in France: A multiple-cause-of-death analysis
}

Thibaud Chazal, Raphael Lhote, Grégoire Rey, Julien Haroche, Mireille Eb, Zahir Amoura, Fleur Cohen Aubart

\section{- To cite this version:}

Thibaud Chazal, Raphael Lhote, Grégoire Rey, Julien Haroche, Mireille Eb, et al.. Giant-cell arteritisrelated mortality in France: A multiple-cause-of-death analysis. Autoimmunity Reviews, 2018, 17 (12), pp.1219-1224. 10.1016/j.autrev.2018.06.012 . hal-01977001

\section{HAL Id: hal-01977001 https: / hal.sorbonne-universite.fr/hal-01977001}

Submitted on 10 Jan 2019

HAL is a multi-disciplinary open access archive for the deposit and dissemination of scientific research documents, whether they are published or not. The documents may come from teaching and research institutions in France or abroad, or from public or private research centers.
L'archive ouverte pluridisciplinaire HAL, est destinée au dépôt et à la diffusion de documents scientifiques de niveau recherche, publiés ou non, émanant des établissements d'enseignement et de recherche français ou étrangers, des laboratoires publics ou privés. 


\section{Giant-cell arteritis-related mortality in France: a multiple-cause-of-death analysis}

Running title: Giant-cell arteritis-related mortality in France

Thibaud Chazal*1, MD, Raphael Lhote*1, MD, Grégoire Rey³, MD, Julien Haroche ${ }^{1,2}$, MD, PhD, Mireille Eb ${ }^{3}, \mathrm{MD}$, Zahir Amoura ${ }^{1,2}, \mathrm{MD}, \mathrm{MSc}$ and Fleur Cohen Aubart ${ }^{1,2}, \mathrm{MD}, \mathrm{PhD}$

\section{Affiliations}

${ }^{1}$ Assistance Publique-Hôpitaux de Paris, Service de Médecine Interne 2, Centre National de Référence Maladies Systémiques Rares, Hôpital Pitié-Salpêtrière, 75013-Paris, France

${ }^{2}$ Sorbonne-Université, Faculté de Médecine - Paris VI, 75013-Paris, France

${ }^{3}$ INSERM CépiDc, Epidemiology Centre on Medical Causes of Death, 94000-Le Kremlin

Bicêtre, France

These authors contributed equally to this work and are co-first authors

\section{Correspondence to:}

Dr. Fleur Cohen Aubart, Service de Médecine Interne 2, Hôpital Pitié-Salpêtrière, 47-83

Boulevard de l'hôpital, 75651 Paris CEDEX 13

Phone +331421782 42; Fax +33142165804

fleur.cohen@aphp.fr

Word count in the text: 2349

Number of Tables: 4

Number of Figures: 2

Number of References: 18

Keywords: giant-cell arteritis, mortality, epidemiology 


\section{Authors contributions}

F.C.A., and Z.A. designed the study.

T.C., R.L., G.R., M.E. and F.C.A. collected the data.

R.L. and F.C.A. conducted the statistical analysis.

T.C., R.L., G.R., J.H., A.M., M.E., Z.A. and F.C.A. analyzed and interpreted the data.

T.C., R.L., G.R. and F.C.A. wrote the manuscript.

All authors critically reviewed and approved the final version of the manuscript.

This work did not receive any financial support.

The authors declare they have no conflicts of interest to report. 


\section{Abstract}

Objectives: Giant-cell arteritis (GCA) is a large vessel vasculitis. Data regarding mortality are controversial. We describe the mortality data of the French death certificates for the period of 2005 to 2014.

Methods: Using multiple-cause-of-death (MCOD) analysis, we calculated age-adjusted mortality rates for GCA, examined differences in mortality rates according to age and gender and analyzed the underlying causes of death (UCD).

Results: We analyzed 4,628 death certificates listing a diagnosis of GCA as UCD or nonunderlying cause of death (NUCD). The mean age of death was $86( \pm 6.8)$ years. The overall age-standardized mortality rate among GCA patients was 7.2 per million population.

Throughout the study period, the mean age of death was significantly increased $(\mathrm{r}=0.17$, $\mathrm{p}<0.0001$ ) in both genders. There was no significant difference with age repartition of death in the general population $(\mathrm{p}=0.26)$. When GCA was listed as the UCD, most frequent associated diseases were cardiovascular (79\%) and infectious diseases (35\%). When GCA was reported as the NUCD, the listed UCD was a cardiovascular event in $40 \%$ of cases, neoplasm in $13 \%$, neurodegenerative disorder in 11\% and infectious disease in 10\%. When GCA was the UCD or NUCD, an age-adjusted observed/expected ratio $>1$ in GCA-associated mortality compared with the general population mortality was observed for tuberculosis, pneumonia and cardiovascular diseases.

Conclusion: In this analysis of French death certificates mentioning GCA, we observed a stable standardized mortality rate between 2005 and 2014. The most frequent associated diseases were cardiovascular diseases and infections.

Word count in abstract: 242 


\begin{tabular}{|c|c|c|c|c|c|c|c|c|c|c|c|}
\hline & 2005 & 2006 & 2007 & 2008 & 2009 & 2010 & 2011 & 2012 & 2013 & 2014 & Total \\
\hline $\begin{array}{l}\text { GCA related } \\
\text { deaths (n) }\end{array}$ & 520 & 483 & 433 & 441 & 501 & 462 & 426 & 465 & 478 & 419 & 4628 \\
\hline $\begin{array}{l}\text { GCA listed as } \\
\text { the UCD }\end{array}$ & 157 & 146 & 120 & 138 & 133 & 116 & 111 & 112 & 132 & 97 & 1262 \\
\hline Male & 44 & 45 & 25 & 43 & 41 & 34 & 35 & 40 & 31 & 21 & 359 \\
\hline Female & 113 & 101 & 95 & 95 & 92 & 82 & 76 & 72 & 101 & 76 & 903 \\
\hline $\begin{array}{l}\text { Female/Male } \\
\text { ratio } \\
\text { Age (years) }\end{array}$ & 2.6 & 2.2 & 3.8 & 2.2 & 2.2 & 2.4 & 2.2 & 1.8 & 3.3 & 3.6 & 2.5 \\
\hline$<70$ & 0 & 3 & 0 & 1 & 1 & 2 & 4 & 4 & 2 & 5 & 23 \\
\hline $70-79$ & 23 & 20 & 20 & 15 & 14 & 17 & 18 & 17 & 13 & 9 & 166 \\
\hline 80-89 & 86 & 77 & 70 & 85 & 71 & 59 & 59 & 43 & 67 & 52 & 671 \\
\hline $90-99$ & 48 & 43 & 28 & 35 & 46 & 34 & 28 & 46 & 47 & 31 & 386 \\
\hline$\geq 100$ & 0 & 2 & 2 & 2 & 1 & 3 & 2 & 2 & 2 & 0 & 16 \\
\hline $\begin{array}{l}\text { GCA listed as a } \\
\text { NUCD }\end{array}$ & 363 & 337 & 313 & 303 & 368 & 346 & 315 & 353 & 346 & 322 & 3366 \\
\hline Male & 112 & 102 & 88 & 92 & 128 & 93 & 97 & 105 & 99 & 97 & 1013 \\
\hline Female & 251 & 235 & 225 & 211 & 240 & 253 & 218 & 248 & 247 & 225 & 2353 \\
\hline $\begin{array}{l}\text { Female/Male } \\
\text { ratio } \\
\text { Age (years) }\end{array}$ & 2.2 & 2.3 & 2.6 & 2.3 & 1.9 & 2.7 & 2.2 & 2.4 & 2.5 & 2.3 & 2.3 \\
\hline$<70$ & 10 & 7 & 12 & 2 & 6 & 3 & 2 & 7 & 3 & 5 & 57 \\
\hline $70-79$ & 64 & 65 & 44 & 55 & 54 & 35 & 29 & 34 & 40 & 33 & 453 \\
\hline 30-89 & 173 & 177 & 165 & 168 & 200 & 207 & 177 & 196 & 181 & 172 & 1816 \\
\hline $90-99$ & 115 & 86 & 88 & 75 & 101 & 97 & 99 & 112 & 119 & 108 & 1000 \\
\hline$\geq 100$ & 1 & 2 & 4 & 3 & 7 & 4 & 8 & 4 & 3 & 4 & 40 \\
\hline $\begin{array}{l}\text { Age- } \\
\text { standardized } \\
\text { mortality rate } \\
\text { All GCA } \\
\text { patients }\end{array}$ & 8.2 & 7.6 & 6.8 & 6.9 & 7.8 & 7.1 & 6.6 & 7.1 & 7.3 & 6.3 & 7.2 \\
\hline $\begin{array}{l}\text { Male } \\
\text { Female }\end{array}$ & $\begin{array}{c}5.1 \\
11.1\end{array}$ & $\begin{array}{c}4.7 \\
10.3\end{array}$ & $\begin{array}{l}3.9 \\
9.5\end{array}$ & $\begin{array}{l}4.5 \\
9.2\end{array}$ & $\begin{array}{c}4.3 \\
11.1\end{array}$ & $\begin{array}{c}3.7 \\
10.4\end{array}$ & $\begin{array}{l}3.5 \\
9.7\end{array}$ & $\begin{array}{c}3.5 \\
10.5\end{array}$ & $\begin{array}{c}4.1 \\
10.2\end{array}$ & $\begin{array}{c}3 \\
9.4\end{array}$ & $\begin{array}{c}4 \\
10.1\end{array}$ \\
\hline $\begin{array}{l}\text { Female/Male } \\
\text { ratio }\end{array}$ & 2.2 & 2.2 & 2.4 & 2 & 2.6 & 2.8 & 2.8 & 3 & 2.5 & 3.1 & 2.5 \\
\hline
\end{tabular}

Table 1. GCA-related deaths in France (2005-2014): absolute numbers, stratified by years 


\begin{tabular}{|c|c|c|c|}
\hline \multicolumn{4}{|l|}{ GCA mentioned as UCD } \\
\hline & Male & Female & Total \\
\hline Cardiovascular disease & 322 (89.7) & $681(75.4)$ & $1003(79)$ \\
\hline Chronic heart disease & $122(34)$ & $244(27)$ & $366(29)$ \\
\hline Ischemic heart disease & $47(13.1)$ & $78(8.6)$ & $125(10)$ \\
\hline $\begin{array}{l}\text { Pulmonary embolism and thromboembolic } \\
\text { disease }\end{array}$ & $21(5.8)$ & $61(6.8)$ & $82(6)$ \\
\hline Stroke & $27(7.5)$ & $55(6)$ & $82(6.4)$ \\
\hline Others & $105(29.2)$ & $243(26.9)$ & $348(27.6)$ \\
\hline Neoplasm & $26(7.2)$ & $46(5.1)$ & $72(5.7)$ \\
\hline Hematologic malignancy & $8(2.2)$ & $16(1.8)$ & $24(1.9)$ \\
\hline Solid malignant neoplasm & $18(5)$ & $30(3.3)$ & $48(3.8)$ \\
\hline Neurodegenerative disease & $44(12.3)$ & $127(14.1)$ & $171(13.5)$ \\
\hline Alzheimer disease & $11(3.1)$ & $35(4)$ & $46(3.6)$ \\
\hline Other dementia & $33(9.2)$ & $92(10.2)$ & $125(9.9)$ \\
\hline Infectious disease & $166(46.2)$ & $287(31.8)$ & $453(35.9)$ \\
\hline Pneumonia & $91(25.3)$ & $149(16.5)$ & $240(9)$ \\
\hline Sepsis and other bacterial infection & $70(19.5)$ & $130(14.4)$ & $200(15.8)$ \\
\hline Tuberculosis and opportunist infection & $4(1.1)$ & $6(0.7)$ & $10(0.8)$ \\
\hline Viral infection & $1(0.3)$ & $2(0.2)$ & $3(0.2)$ \\
\hline Accidental death & $38(10.6)$ & $58(6.4)$ & $96(7.6)$ \\
\hline Traumatic death & $13(3.6)$ & $23(2.5)$ & $36(2.9)$ \\
\hline Accidental exposition & $2(0.6)$ & $4(0.4)$ & $6(0.5)$ \\
\hline Iatrogenic complication & $23(6.4)$ & $31(3.4)$ & $54(4.3)$ \\
\hline Suicide & $0(0)$ & $0(0)$ & $0(0)$ \\
\hline Acute digestive disease & $15(4.2)$ & $42(4.7)$ & $57(4.5)$ \\
\hline $\begin{array}{l}\text { Digestive hemorrhage and digestive } \\
\text { perforation }\end{array}$ & $9(2.5)$ & $15(1.7)$ & $24(1.9)$ \\
\hline Other digestive disease & $6(1.7)$ & $27(3)$ & $33(2.6)$ \\
\hline Other chronic disease & $140(39)$ & $208(23)$ & $348(27.6)$ \\
\hline Chronic respiratory disease & 57 (15.9) & $78(8.6)$ & $135(10.7)$ \\
\hline Renal disease & 39 (10.9) & $61(6.8)$ & $100(7.9)$ \\
\hline Autoimmune disease & $8(2.2)$ & $19(2.1)$ & $27(2.1)$ \\
\hline Hepatic disease & $1(0.3)$ & $1(0.1)$ & $2(0.2)$ \\
\hline Diabetes & $35(9.8)$ & $49(5.4)$ & $84(6.7)$ \\
\hline Other & $88(24.5)$ & $242(26.8)$ & $330(26.1)$ \\
\hline Total & $359(100)$ & $903(100)$ & $1262(100)$ \\
\hline
\end{tabular}

Table 2. Associated diseases mentioned as non-underlying causes of death (NUCD) when GCA was mentioned as the underlying cause of death (UCD) in the death certificates of patients with GCA in France (2005-2014)

Data are presented as n (\%). 


\begin{tabular}{|c|c|c|c|}
\hline \multicolumn{4}{|l|}{ GCA mentioned as NUCD } \\
\hline & Male & Female & Total \\
\hline Cardiovascular disease & $384(37.9)$ & $977(41.5)$ & $1361(40.4)$ \\
\hline Chronic heart disease & $132(13)$ & $343(14.6)$ & $475(14.1)$ \\
\hline Ischemic heart disease & $79(7.8)$ & $188(8)$ & $267(7.9)$ \\
\hline $\begin{array}{l}\text { Pulmonary embolism and thromboembolic } \\
\text { disease }\end{array}$ & $17(1.7)$ & $41(1.7)$ & $58(1.7)$ \\
\hline Stroke & $101(10)$ & $256(10.9)$ & $357(10.6)$ \\
\hline Other & $55(5.4)$ & $149(6.3)$ & $204(6.1)$ \\
\hline Neoplasm & $181(17.8)$ & $262(11.1)$ & $443(13.2)$ \\
\hline Hematologic malignancy & $46(4.5)$ & $70(3)$ & $116(3.5)$ \\
\hline Solid malignant neoplasm & $135(13.3)$ & $192(8.1)$ & $327(9.7)$ \\
\hline Neurodegenerative disease & $81(8)$ & $297(12.6)$ & $378(11.2)$ \\
\hline Alzheimer disease & $26(2.6)$ & $148(6.3)$ & $174(5.1)$ \\
\hline Other dementia & $55(5.4)$ & $149(6.3)$ & $204(6.1)$ \\
\hline Infectious disease & $112(11.1)$ & $220(9.3)$ & $332(9.9)$ \\
\hline Pneumonia & $33(3.4)$ & $53(2.2)$ & $87(2.6)$ \\
\hline Sepsis and other bacterial infection & $62(6.1)$ & $132(5.6)$ & $194(5.8)$ \\
\hline Tuberculosis and opportunist infection & $11(1.1)$ & $20(0.9)$ & $31(0.9)$ \\
\hline Viral infection & $5(0.5)$ & $15(0.6)$ & $20(0.6)$ \\
\hline Accidental death & $58(5.8)$ & $145(6.1)$ & $203(6)$ \\
\hline Traumatic death & $29(2.9)$ & $98(4.1)$ & $127(3.8)$ \\
\hline Accidental exposition & $10(1)$ & $30(1.3)$ & $40(1.2)$ \\
\hline Iatrogenic complication & $6(0.6)$ & $13(0.5)$ & $19(0.5)$ \\
\hline Suicide & $13(1.3)$ & $4(0.2)$ & $17(0.5)$ \\
\hline Acute digestive disease & $28(2.8)$ & $97(4.1)$ & $125(3.7)$ \\
\hline $\begin{array}{l}\text { Digestive hemorrhage and digestive } \\
\text { perforation }\end{array}$ & $8(0.8)$ & $43(1.8)$ & $51(1.5)$ \\
\hline Other digestive disease & $20(2)$ & $54(2.3)$ & $74(2.2)$ \\
\hline Other chronic disease & $120(11.8)$ & $219(9.3)$ & $339(10.1)$ \\
\hline Chronic respiratory disease & $48(4.7)$ & $63(2.6)$ & $111(3.3)$ \\
\hline Renal disease & $21(2.1)$ & $37(1.6)$ & $58(1.7)$ \\
\hline Autoimmune disease & $7(0.7)$ & $25(1.1)$ & $32(1)$ \\
\hline Hepatic disease & $2(0.2)$ & $3(0.1)$ & $5(0.2)$ \\
\hline Diabetes & $42(4.1)$ & $91(3.9)$ & $133(3.9)$ \\
\hline Other & $49(4.8)$ & $136(5.7)$ & $185(5.5)$ \\
\hline Total & $1013(100)$ & $2353(100)$ & $3366(100)$ \\
\hline
\end{tabular}

Table 3. Associated diseases mentioned as underlying causes of death (UCD) when GCA was mentioned as the non-underlying cause of death (NUCD) in the death certificates of patients with GCA in France (2005-2014)

Data are presented as n (\%). 


\begin{tabular}{|c|c|c|c|c|}
\hline & $\begin{array}{c}\text { Observed/ expected } \\
\text { ratio } \\
65-85 \text { years } \\
\end{array}$ & p-value & $\begin{array}{c}\text { Observed/ } \\
\text { expected ratio } \\
>85 \text { years } \\
\end{array}$ & p-value \\
\hline \multicolumn{5}{|l|}{ GCA as UCD } \\
\hline \multicolumn{5}{|l|}{ Infectious disease } \\
\hline Tuberculosis & $9.9(3.6-21.9)$ & $<0.001$ & $4.4(1.2-11.4)$ & 0.006 \\
\hline Pneumonia & $16.8(13.2-21.1)$ & $<0.001$ & $6.5(5.4-7.8)$ & $<0.001$ \\
\hline \multicolumn{5}{|l|}{ Vascular disease } \\
\hline Ischemic heart disease & $1.7(1.3-2.3)$ & $<0.001$ & $1.2(0.9-1.5)$ & 0.5 \\
\hline Cerebrovascular disease & $1.2(0.8-1.8)$ & 0.3 & $0.8(0.5-1.01)$ & 0.07 \\
\hline \multicolumn{5}{|l|}{ Neoplasm } \\
\hline $\begin{array}{l}\text { Solid malignant } \\
\text { neoplasm }\end{array}$ & $0.12(0.08-0.2)$ & $<0.001$ & $0.2(0.1-0.3)$ & $<0.001$ \\
\hline Hematologic malignancy & $0.9(0.5-1.5)$ & 0.8 & $0.5(0.2-1.0)$ & 0.08 \\
\hline \multicolumn{5}{|l|}{ GCA as NUCD } \\
\hline \multicolumn{5}{|l|}{ Infectious disease } \\
\hline Tuberculosis & $12.3(7.6-18.9)$ & $<0.001$ & $4.3(2.0-7.9)$ & $<0.001$ \\
\hline Pneumonia & $1.5(1.01-2.2)$ & 0.04 & $0.8(0.6-1.1)$ & 0.2 \\
\hline \multicolumn{5}{|l|}{ Vascular disease } \\
\hline Ischemic heart disease & $0.9(0.7-1.1)$ & 0.5 & $1.2(1.01-1.4)$ & 0.03 \\
\hline Cerebrovascular disease & $2.4(2.0-2.8)$ & $<0.001$ & $1.2(1.04-1.4)$ & 0.01 \\
\hline \multicolumn{5}{|l|}{ Neoplasm } \\
\hline $\begin{array}{l}\text { Solid malignant } \\
\text { neoplasm }\end{array}$ & $0.3(0.3-0.4)$ & $<0.001$ & $0.6(0.5-0.7)$ & $<0.001$ \\
\hline Hematologic malignancy & $1.4(1.1-1.8)$ & $<0.001$ & $1.2(0.9-1.6)$ & 0.2 \\
\hline
\end{tabular}

Table 4. Age-adjusted observed/expected ratios for the underlying cause of death (UCD) when GCA was a non-underlying cause of death (NUCD)

Data are presented as observed/expected ratio (95\% confidence interval). 


\section{Introduction}

Giant-cell arteritis (GCA) is a large-vessel vasculitis usually affecting individuals over 50 years old, typically presenting with unilateral or bilateral headache, myalgias, fatigue, fever, weight loss, and sometimes acute vision loss [1]. It is frequently associated with polymyalgia rheumatica (PMR), which represents either a different manifestation of the same disease or overlapping conditions. Both diseases are associated with an inflammatory state with an increased erythrocyte sedimentation rate (ESR) and/or C-reactive protein (CRP), and the treatment relies mainly on corticosteroids, usually prescribed for a prolonged period. GCA seems to affect predominantly European populations, especially those of northern European descent, and is slightly more common in women than in men, with a lifetime risk of GCA estimated at $1.0 \%$ in women versus $0.5 \%$ in men $[2,3]$. GCA is the most frequent primary vasculitis with an estimated incidence in the United States of 18 per 100,000, but data based on recent studies suggest that GCA incidence has stabilized or even decreased in recent years $[4,5]$. Data regarding GCA mortality are controversial. A recent meta-analysis including 17 studies found no difference in long-term mortality between GCA patients and the general population (mortality odds ratio of 1.03), except in GCA patients recruited through a hospital setting (mortality odds ratio of 1.61), especially in the first two years following GCA diagnosis [6]. Mortality in GCA has been attributed to specific complications of the disease, particularly aortic aneurysms and cerebrovascular events associated with a lower survival $[5,7,8]$. Some studies also showed increased cardiovascular mortality and increased mortality due to infectious diseases in GCA patients compared with general population $[9,10]$. To better characterize mortality causes in GCA, we examined data from death certificates compiled by the French Epidemiological Centre on Medical Causes of Death (CépiDc, Institut National de la Santé et de la Recherche Médicale) between 2005 and 2014. Using multiplecause-of-death (MCOD) analysis, we calculated age-adjusted mortality rates for GCA, examined differences in mortality rates according to age and gender and recorded the 
underlying causes of death (UCD).

\section{Methods}

\section{Data extraction}

Data were extracted from the Institut National de la Statistique et des études économiques (INSEE) database for population analysis and from the CépiDc database for causes of death analysis. Since 2000, CépiDc has recorded all death certificates issued in France, and these anonymized data are available to researchers. French death certificates consist of 2 parts and comply with the World Health Organization standards. Part I lists the "diseases related to the morbid process leading to death" in reverse order of causality. If the death certificate is correctly filled, the last condition listed is generally defined as the UCD. Part II reports on “other significant conditions contributing to death, but not related to the disease or condition listed on part I". Other diseases than UCD are considered as non-underlying causes of death (NUCD). All data are coded in a database following the guidelines of the International Classification of Diseases, 10th Revision. For the study period, we obtained data from all death certificates that mentioned GCA either as the UCD or a NUCD. Only data from decedents aged $\geqslant 18$ years were analyzed.

\section{Statistical analysis}

All death certificates that listed GCA as the UCD or NUCD, whatever its place on the death certificate, were considered in the MCOD analysis. Gender and age at time of death were extracted. Direct age standardization with the general French population as a reference was applied to calculate mortality rates and estimated by year and for the study period. Mortality rates were categorized according to age group for the entire study period. Categorical variables are presented as absolute values (with percentages), whereas continuous variables are shown as the mean \pm standard deviation (SD). The numbers of deaths were compared according to gender, age and the cause of death (UCD or NUCD) using the chi-squared or 
Fisher's exact test. Proportions of GCA listed either as the UCD or a NUCD were studied over time, with the linear trend tested over time. Linear regression and t-tests were used to compare the age at death by year and gender, respectively. Linear regressions were used to compare standardized mortality rates overall by gender and age range. Differences were considered statistically significant when $\mathrm{p}<0.05$. R software version 3.0.2 (www.rproject.org/foundation/] was used for the statistical analyses.

\section{Results}

\section{Numbers of deaths with GCA in France between 20015 and 2014}

Between 2005 and 2014, 5,311,098 adults died in France. Among them, the CépiDc recorded 4,628 death certificates reporting a diagnosis of GCA as UCD or NUCD. The absolute numbers of deaths with GCA listed as UCD or NUCD, stratified by year during the study period, are shown in Table 1. The mean number of annual deaths was $462( \pm 33.4)$ and $51.2 \%$ of them occurred in hospital. The mean age of death was $86( \pm 6.8)$ years: $84.6( \pm 6.9)$ years in men and $86.7( \pm 6.6)$ years in women $(p<0.001)$. Throughout the study period, the mean age of death was significantly increased $(r=0.17, p<0.0001)$ (Figure 1), more in men $(r=0.21, p=0.001)$ than in women $(\mathrm{r}=0.15, \mathrm{p}=0.001)$. We observed that $99.4 \%$ of all GCA-related deaths occurred after 65 years and $62.6 \%$ after 85 years. There was no significant difference with the age repartition of death in the general population $(p=0.26)$, according to the year of death. The ratio of females to males was 2.4 (1,372 men versus 3,256 women) and remained stable throughout the study period.

\section{Age-standardized mortality rate in GCA}

The overall age-standardized mortality rate (ASMR) among GCA patients was 7.2 per million and remained stable between 2005 and 2014 ( $r=-3.3, p=0.056)$ (Table 1). However, for men, ASMR decreased significantly throughout the study period $(r=-4, p=0.003$ ) (Figure 2). 


\section{Associated diseases in death certificates mentioning GCA}

GCA was listed as the UCD in 1,262 death certificates (27\%) and as a NCUD in 3,366 death certificates (73\%). There was no significant difference between UCD and NUCD notification according to gender or age $(p=0.29$ and $p=0.10$, respectively) but in-hospital mortality was higher when GCA was listed as a NUCD ( $p<0.001)$. There was no significant difference in the age repartition of the notification as the UCD or a NUCD $(p=0.10)$.

The GCA-associated diseases mentioned in the death certificates are detailed in Tables $\mathbf{2}$ and

3. When GCA was listed as the UCD (Table 2), most common associated diseases were cardiovascular (79\%) and infectious diseases (35\%). Cardiovascular disease included congestive heart failure in $29 \%$ of death certificates, ischemic heart disease in $10 \%$ and strokes in $6 \%$.

When GCA was reported as the NUCD (Table 3), the listed UCD was cardiovascular events in $40 \%$ of patients including strokes in 10\%, neoplasms in 13\% (mostly solid neoplasms), neurodegenerative disorders in $11 \%$ and infectious diseases in $10 \%$.

Cardiovascular diseases (listed as UCD or NUCD) were stable during the study period $(\mathrm{R}=$ 0.005, $\mathrm{p}=0.053$ ) although infectious diseases (UCD or NUCD: $\mathrm{R}=0.01, \mathrm{p}=0.01$ ), neoplasms (UCD or NUCD: $R=0.004, p=0.04$ ) and neurodegenerative diseases (UCD or NUCD: $R=0.006$, $\mathrm{p}=0.01$ ) increased during the study period.

\section{Observed/expected ratio}

Observed/expected ratio (O/E ration) are detailed in the Table 4. When GCA was the UCD, an 0/E ratio >1 in GCA-associated mortality compared with the general population's mortality was observed for tuberculosis between 65 and 85 years $(0 /$ E ratio $=9.9, p<0.001)$ and after 85 years $(\mathrm{O} / \mathrm{E}$ ratio $=4.4, \mathrm{p}=0.01)$. An $0 /$ E ratio $>1$ was also observed for pneumonia between 65 and 85 years $(0 /$ E ratio $=16.8, \mathrm{p}<0.001)$ and after 85 years $(0 /$ E ratio $=6.5, \mathrm{p}<0.001)$. When GCA was the NUCD, an 0/E ratio >1 was observed for tuberculosis between 65 and 85 years $(0 /$ E ratio $=12.3, \mathrm{p}<0.001)$ and after 85 years $(0 /$ E ratio $=4.3, \mathrm{p}<0.001)$. For 
pneumonia, an 0/E ratio > 1 was also observed between 65 and 85 years $(0 /$ E ratio $=1.5$, p=0.04). An 0/E ratio >1 in GCA-associated mortality was observed for cerebrovascular disease between 65 and 85 years $(\mathrm{O} / \mathrm{E}$ ratio $=2.4, \mathrm{p}<0.001)$ and after 85 years $(0 / \mathrm{E}$ ratio $=$ $1.2, \mathrm{p}=0.01)$ and for hematologic malignancy between 65 and 85 years $(\mathrm{O} / \mathrm{E}$ ratio $=1.4$, $\mathrm{p}<0.001$ ).

\section{Discussion}

Using the CépiDc database containing all French death certificates, we found that there was no significant difference in the age repartition of death when GCA was mentioned in the death certificate compared to that of the general population, suggesting that GCA is associated with a survival reflecting the age incidence of this disease. These results are consistent with a recent international meta-analysis that found that long-term mortality was not increased in GCA $[3,6]$. In a Northern Italian study, no significant differences in mortality rates were observed between GCA and non-GCA subjects [11]. Moreover, no significant differences in the cause of death were observed comparing GCA patients to non-GCA subjects. Conversely, in a Danish study, the relative risk of death in patients diagnosed with GCA compared to the general population was 1.17 (95\% CI 1.01, 1.36) and 1.22 (95\% CI 1.05, 1.41) 0-2 years and $>10$ years after diagnosis, respectively, whereas they observed no increased mortality during the follow-up period of 2-10 years [12]. In the Swedish study, mortality was significantly increased over the first 2 years after GCA diagnosis but not with longer follow-up. The estimated excess mortality was greater in women and in patients aged $\leq 70$ years at diagnosis [4]. Recently, a UK study found that compared with non-vasculitis patients, GCA patients had increased mortality during the first year following diagnosis but not $>5$ years after the diagnosis [13]. GCA patients diagnosed before age 65 had the highest mortality risk during the first year following diagnosis (adjusted $\mathrm{HR}=2.32,95 \%$ CI 1.60-3.35). The design of the present study, which was not longitudinal, could not allow assessing the time between GCA diagnosis 
and death on GCA mortality.

In our study, we found that the mortality risk did not differ substantially by sex or calendar year, as was the case in the UK study [13].

In our study, GCA was considered the underlying cause of death in $27 \%$ of patients with GCA mentioned in the death certificates. The most common associated diseases were cardiovascular disease and infectious diseases. These associated diseases are the most commonly reported in GCA epidemiologic studies. An Australian study found 71 deaths among 225 patients with biopsy-proven GCA and deaths from cardiovascular causes (45\%) were the most common, followed by infection (17\%) and cancer (17\%) [14]. Increased cardiovascular mortality has been reported in GCA in 2 different settings. Some cardiovascular complications, including aortic aneurysms and ischemic strokes are predominantly associated with mortality in the early phase of the disease, usually in the 2 years after GCA diagnosis, suggesting a prevailing role of inflammatory mechanisms directly related to the vasculitis $[12,15]$. In previous studies, ischemic strokes were a leading cause of death during GCA [8]. In the Danish study, the increased mortality during the first 2 years of follow-up was mainly due to diseases of the circulatory system, including aortic aneurisms [12]. In a large US study from 1950 to 2009, patients with GCA and aortic manifestations had a higher than expected number of deaths from cardiovascular and pulmonary causes than those of the general population, and manifestations were associated with increased mortality in GCA patients (HR=3.4; 95\% CI 2.2 to 5.4) [5]. Cardiovascular complications may also occur after the 2 first years of the disease and may be driven by prolonged corticosteroid treatment [4]. Venous thrombosis (VT) and pulmonary embolism (PE) were also reported as a common feature during GCA [16]. In our study, we found that VT and PE accounted for 150 cases over 10 years, as the UCD or NUCD. VT and PE may be limited to GCA in-patients, who typically have a low mortality rate [17]. Infectious complications have been reported with a higher frequency in GCA, particularly in 
the first year after GCA diagnosis and have been associated with older age, pre-existing diabetes and prolonged use of corticosteroids [10]. In a French prospective study, severe infections were more common among patients with GCA during the first year after diagnosis compared to general population controls. In particular, septic shock and infectious colitis were more common among the patients with GCA, and mortality caused by infections was higher in patients with GCA than in the controls [10]. In our study, a positive association (0/E ratio $>1$, GCA being listed as the UCD or NUCD) was observed between GCA and pneumonia and GCA and tuberculosis. This association was stronger before 85 years and decreased with age. In a recent study using death certificates in France, deaths from cardiovascular and potentially treatment-related causes were also overrepresented in decedents with GCA [18]. Conversely, GCA was associated with decreased risk of death caused by malignant neoplasms, as in our study. The period study was different, starting in 1980 through 2011. Management of GCA may have changed during the past 30 years and we present here the more recent data, focusing on the 2005-2014 period.

Our study has several limitations. Since the assessment of UCD and NCUD on the death certificate is left to the physician's judgment, GCA may not have been declared for patients with a long time from diagnosis to death or in patients considered in remission. Moreover, the physicians did not mention GCA if they consider that if has not contributed to death. On the other hand, for patients with more severe disease, GCA was probably more likely to be reported as UCD or NUCD. The distinction between UCD and NUCD is also difficult to appraise in GCA. Some individuals may consider complications such as aortic aneurysm or ischemic stroke as UCD, while others consider them NUCD.

\section{Conclusions}

Despite limitations, our study suggests that overall mortality is not strongly increased in GCA patients and remained stable between 2005 and 2014, suggesting that there was no 
improvement in the treatments during the period. Most common comorbidities were cardiovascular and infectious diseases, which can both be considered complications of GCA but also long-term complications of GCA treatment, especially corticosteroid treatment. Improving our knowledge on mortality in GCA will help determine important actions to prevent long-term complications of the disease. 
Figure legends

Figure 1. Evolution of the mean age at death over the study period

Mean age at death increased over the study period $(\mathrm{r}=0.17, \mathrm{p}<0.0001)$

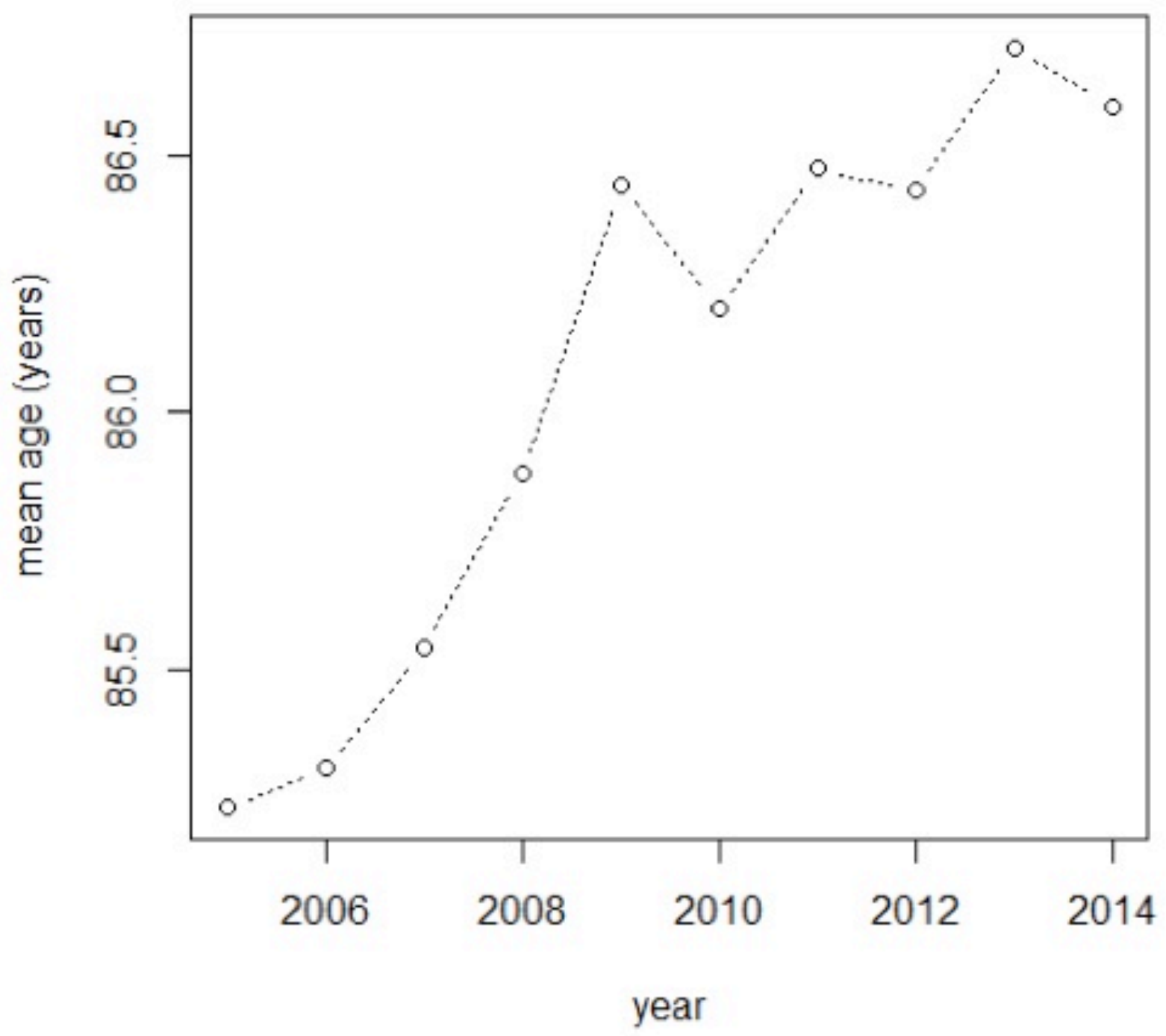


Figure 2. Age-standardized mortality rate (ASMR) stratified by gender (A: both sexes; B: men; C: women)

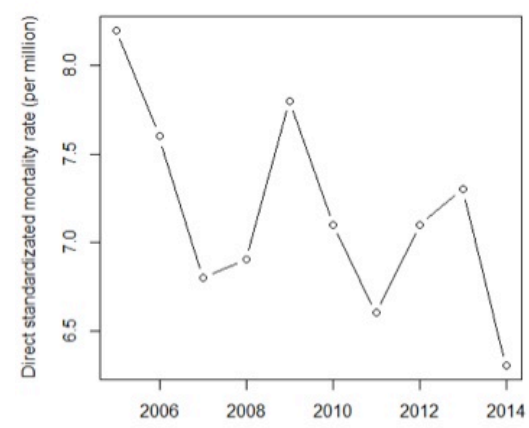

A

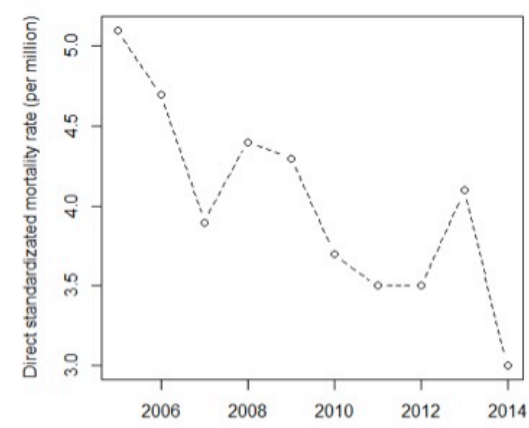

B

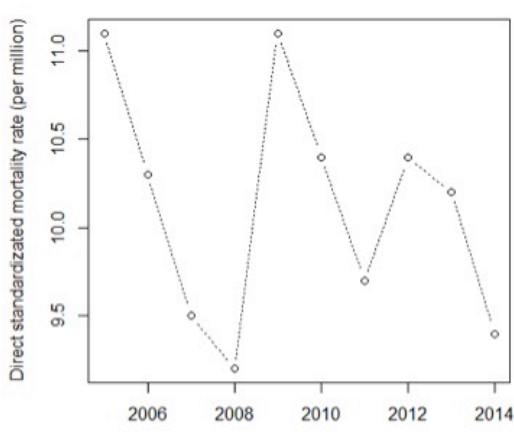

C year 
[1] C.M. Weyand and J.J. Goronzy, Clinical practice. Giant-cell arteritis and polymyalgia rheumatica, N Engl J Med 371 (2014) 50-7.

[2] C.S. Crowson, E.L. Matteson, E. Myasoedova, C.J. Michet, F.C. Ernste, K.J. Warrington, J.M. Davis, 3rd, G.G. Hunder, T.M. Therneau and S.E. Gabriel, The lifetime risk of adultonset rheumatoid arthritis and other inflammatory autoimmune rheumatic diseases, Arthritis and rheumatism 63 (2011) 633-9.

[3] A. Mahr, A. Aouba, P. Richebe and S. Gonzalez-Chiappe, [Epidemiology and natural history of giant cell arteritis], Rev Med Interne 38 (2017) 663-669.

[4] A.J. Mohammad, J.A. Nilsson, L.T. Jacobsson, P.A. Merkel and C. Turesson, Incidence and mortality rates of biopsy-proven giant cell arteritis in southern Sweden, Ann Rheum Dis 74 (2015) 993-7.

[5] T.A. Kermani, K.J. Warrington, C.S. Crowson, S.R. Ytterberg, G.G. Hunder, S.E. Gabriel and E.L. Matteson, Large-vessel involvement in giant cell arteritis: a population-based cohort study of the incidence-trends and prognosis, Ann Rheum Dis 72 (2013) 1989-94.

[6] C.L. Hill, R.J. Black, J.C. Nossent, C. Ruediger, L. Nguyen, J.V. Ninan and S. Lester, Risk of mortality in patients with giant cell arteritis: A systematic review and meta-analysis, Seminars in arthritis and rheumatism 46 (2017) 513-519.

[7] P. Ungprasert, K. Wijarnpreecha, M.J. Koster, C. Thongprayoon and K.J. Warrington, Cerebrovascular accident in patients with giant cell arteritis: A systematic review and metaanalysis of cohort studies, Seminars in arthritis and rheumatism 46 (2016) 361-366.

[8] T. Chazal, P. Couture, C. Rosso, J. Haroche, A. Leger, B. Hervier, S. Deltour, P. Rufat, Z. Amoura and F. Cohen Aubart, Cerebrovascular events are associated with lower survival in giant cell arteritis: A case-controlled multicenter study, Joint, bone, spine : revue du rhumatisme (2017).

[9] A. Uddhammar, A.L. Eriksson, L. Nystrom, R. Stenling and S. Rantapaa-Dahlqvist, Increased mortality due to cardiovascular disease in patients with giant cell arteritis in northern Sweden, The Journal of rheumatology 29 (2002) 737-42.

[10] J. Schmidt, A. Smail, B. Roche, P. Gay, V. Salle, H. Pellet and P. Duhaut, Incidence of Severe Infections and Infection-Related Mortality During the Course of Giant Cell Arteritis: A Multicenter, Prospective, Double-Cohort Study, Arthritis Rheumatol 68 (2016) 1477-82.

[11] M. Catanoso, P. Macchioni, L. Boiardi, F. Muratore, G. Restuccia, A. Cavazza, N. Pipitone, P. Mancuso, F. Luberto and C. Salvarani, Incidence, Prevalence, and Survival of BiopsyProven Giant Cell Arteritis in Northern Italy During a 26-Year Period, Arthritis care \& research 69 (2017) 430-438.

[12] B. Baslund, M. Helleberg, M. Faurschou and N. Obel, Mortality in patients with giant cell arteritis, Rheumatology 54 (2015) 139-43.

[13] L. Li, T. Neogi and S. Jick, Mortality in Patients with Giant Cell Arteritis: A Cohort Study in UK Primary Care, Arthritis care \& research (2018).

[14] J. Ninan, A.M. Nguyen, A. Cole, M. Rischmueller, T. Dodd, P. Roberts-Thomson and C.L. Hill, Mortality in patients with biopsy-proven giant cell arteritis: a south australian population-based study, The Journal of rheumatology 38 (2011) 2215-7.

[15] S.L. Mackie and B. Dasgupta, Vasculitis syndromes: Dealing with increased vascular risk and mortality in GCA, Nat Rev Rheumatol 10 (2014) 264-5.

[16] K.H. Ly, E. Liozon, F. Dalmay, G. Gondran, S. Palat, H. Bezanahary, F.X. Lapebie, A. Cypierre, S. Nadalon, P.M. Preux and A.L. Fauchais, Venous thrombosis in patients with giant cell arteritis: Features and outcomes in a cohort study, Joint, bone, spine : revue du rhumatisme 84 (2017) 323-326.

[17] S. Unizony, M.E. Menendez, N. Rastalsky and J.H. Stone, Inpatient complications in patients with giant cell arteritis: decreased mortality and increased risk of thromboembolism, 
delirium and adrenal insufficiency, Rheumatology 54 (2015) 1360-8.

[18] A. Aouba, S. Gonzalez Chiappe, M. Eb, C. Delmas, H. de Boysson, B. Bienvenu, G. Rey and A. Mahr, Mortality causes and trends associated with giant cell arteritis: analysis of the French national death certificate database (1980-2011), Rheumatology (2018). 